\title{
Structure of Plankton Community in the Komering River of Palembang City Area South Sumatra
}

\author{
Yosafat Tawanggian ${ }^{1}$, Effendi Parlindungan Sagala ${ }^{1}$, Zazili Hanafiah ${ }^{1}$

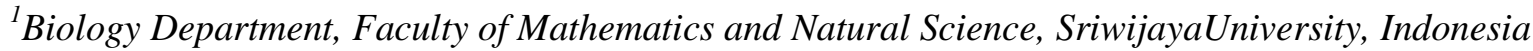 \\ Email: yosafattawanggian@gmail.com
}

\begin{tabular}{llll} 
Article history & & \\
\hline Received & Received in revised form & Accepted & Available online \\
25 March 2019 & 26 December 2019 & 28 December 2019 & 08 March 2020 \\
\hline
\end{tabular}

\begin{abstract}
The research about structure of plankton community and water quality. Research on structure of Plankton Community in the area of Komering River in the Palembang City of South Sumatera had conducted in February - April 2017. The sampling location was Determination based to Purposive Sampling method, namely based on difference of environmental around. The identification of plankton samples was done at Laboratory of Animal Ecology, Biologi Department, Faculty of Mathematics and Natural Science, Sriwijaya University, Indralaya. The results of riset 16 plankton genera consisting of 10 class: Bacillariophyceae, Chloropyceae, Fragilariophyceae, Cyanophyceae, Xanthophyceae, Flagellata, Rizophoda, Crustacea, Branchiopoda, and Nematodes. The ranges of Plankton abundance in the Komering River is low between 1 individual / liter - 91 individuals / liter. The index of spesies diversity of where 0.88 to 1.18 , this mine is medium categories. The Plankton Dominan Index at agriculture area and upstream resettlement area are dominant genera, with value 40.56 and 0.62 , which shows the existence of plankton species that dominate and based on the value of the similarity index shows that between stations research has a high similarity Ranging from $40 \%-82 \%$. While Physicalchemical factors in the waters of the river is classified as stable.
\end{abstract}

Keywords : Plankton Community, Komering River, South Sumatera.

\begin{abstract}
Abstrak: Penelitian ini bertujuan untuk mengetahui Struktur Komunitas Plankton, dan bagaimana kondisi Fisika dan Kimia dan menggambarkan kondisi perairan berdasarkan biota perairan Waktu penelitian berlangsung pada bulan Februari - April 2017. Penentuan lokasi pengambilan sampel dilakukan dengan metode Purposive Sampling, yaitu berdasarkan perbedaan rona lingkungan sekitar. Identifikasi sampel plankton dilakukan di Laboratorium Ekologi Hewan, Jurusan Biologi, Fakultas Matematika dan Ilmu Pengetahuan Alam, Universitas Sriwijaya, Indralaya. Hasil penelitian didapatkan 16 genera plankton yang terdiri dari 10 Kelas yaitu Bacillariophyceae, Chloropyceae, Fragilariophyceae, Cyanophyceae, Xanthophyceae, Flagellata, Rizophoda, Crustacea, Branchiopoda, dan Nematoda . Kelimpahan Plankton pada perairan Sungai Komering tergolong rendah - tinggi yaitu berkisar antara 1 individu/liter - 91 individu/liter. Indeks keanekaragaman jenis tergolong kategori sedang yaitu berkisar antara 0,88-1,18. Indeks Dominansi plankton di daerah pertanian dan pemukiman hulu memiliki nilai 0,57 dan 0,62, yang menunjukan adanya spesies plankton yang mendominansi dan berdasarkan nilai Indeks Kesamaan menunjukan bahwa antar stasiun penelitian memiliki kesamaan yang tinggi yaitu berkisar antara $40 \%$ 82\%. Sedangkan Faktor fisika-kimia perairan pada sungai ini tergolong dalam kondisi stabil.

Kata kunci : Komunitas Plankton, Perairan Sungai Komering, Sumatera Selatan.
\end{abstract}

\section{Introduction}

The Komering River is a river that flows from Oku Regency to Palembang City. This komering river empties into the Musi River. In the upper reaches of the Komering River, there are rice fields and agricultural land, while in the middle of the Komering River there are activities of people living around the river. While downstream there are many industrial activities and also domestic activities.

This river is a fairly large river because this river has a length of approximately 360 kilometers and empties into the Musi river. The komering river has a length of about $360 \mathrm{~km}$. Various activities can take the form of industrial activities, plantations, agriculture, and household activities, which enter river waters. This activity can result in exposure to toxic substances into the river body. This can also have an impact on aquatic biota and health if it is consumed by humans [1].

The existence of these activities will result in short and long term effects on the waters of the River. The short-term effects can be in the form of rubbish, while the long-term effect is a decrease in the productivity level of aquatic organisms in the 
komering river waters. Water organisms that live in rivers include nekton, benthos, periphiton, neuston, and plankton. Functionally, plankton can be classified into four groups major, namely phytoplankton, zooplankton, bacterioplankton, and virioplankton [2]. The fertility of a waters can be seen from the presence of plankton organisms, because of plankton in a waters can describe the level of productivity of these waters.

Plantation, domestic and industrial activities around the river are expected to further worsen river water quality. Based on this statement, a research study was carried out aimed at analyzing the physical-chemical waters quality of water related to their influence on the presence of plankton which play an important role in the life of fish biota in the komering river waters. Plankton can be used as an indicator of biological occurrence water pollution. Polluted waters cause structural changes especially the plankton community and species diversity [3]. This study aims to determine the Plankton Community Structure, and how Physics and Chemistry conditions and describe the condition of the waters based on aquatic biota (plankton).

\section{Materials and Methods}

This research was conducted in February-April 2017 at the Komering River Region of Palembang City, South Sumatra. Determination of stations is determined by the Purposive Sampling method, namely the sampling method by selecting the area that represents the research location, namely in the downstream area / river estuary, residential areas, paddy fields / plantations and residential areas that represent the upstream part of the river. The sampling was done by clustered sampling method. That was done by taking samples at the point $3 \mathrm{x}$ different repetitions. They were combined in one place or one bottle. Measurements of physical and chemical parameters were carried out directly during sampling in the field, while Plankton's observation and identification was carried out at the Laboratory of Animal Ecology and Physiology, Department of Biology, Faculty of Mathematics and Natural Sciences, Sriwijaya University, Indralaya.

\subsection{Location of sampling}

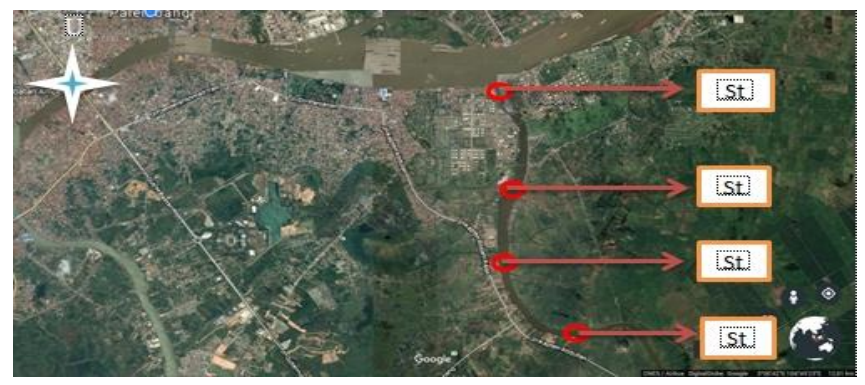

Figure 1. Map of Komering river and Station Point for sampling.

Source: (Google Earth, 2017).

Station Point for sampling :

St 1 : Komering River Estuary Area

$$
\text { (S: } 02{ }^{\circ} 59 \text { '28,3”, E: } 104^{\mathrm{O}} 50 \text { '11,1"); }
$$

St 2 : Resettlement Area

$$
\text { (S: } \left.03^{0} 00^{\prime} 23,5^{\prime \prime}, \mathrm{E}: 104^{0} 50^{\prime} 22,0^{\prime \prime}\right) \text {; }
$$

St 3 : Agricultural area

$$
\text { (S: } 03^{0} 00^{\prime} 44,2 ", \text { E: } 104^{0} 50^{\prime} 08,2 \text { '); }
$$

St 4 : Upstream Settlement Area

$$
\text { (S: } \left.03^{0} 01 \text { ' 12,7”, E: } 104^{0} 50^{\prime} 11,1^{\prime \prime}\right) \text {. }
$$

\subsection{Plankton Sampling}

Sampling is done once, each station taken 3 points. Sampling time is done between 08.00-15.00 WIB. Sampling was carried out using a bucket (10 liters) 3 times repetition by filtering water as much as 5 buckets of water which is equivalent to 50 liters. Water is taken by pouring it into the mouth of plankton net no.25. The results of the plankton filter are poured into a flakon bottle and then preserved with 3-5\% formalin solution of 3-5 drops. The sample bottle is closed using plastic and labeled with the station number, station position (coordinates), date and time of sampling.

\subsection{Plankton Identification}

Identification of plankton is carried out in the laboratory to the genera level, the bottle containing the plankton sample is shaken slowly by turning the bottle to 3 to 4 times until it is homogeneous. Samples were taken using a pipette, and then dropped into a $1 \mathrm{ml}$ Sedgwick Rafter Counting Cell to be observed under a microscope with a 10 x 10 magnification. Observations were made 3 times. Then identify the type of plankton using the plankton identification manual from:

a. Fresh Water Biology Second Edition [4]

b. Ilustrations of the Fresh Water Plankton of Japan[5]

c. Planktonologi [6]

\subsection{Measurement of Physical and Chemical Factors \\ 2.4.1. Temperature $\left({ }^{\circ} \mathrm{C}\right)$}

Measurement of temperature in the water is carried out in situ or carried out directly in the field. How it works from measuring the level of water temperature is Measurement of water temperature can immediately dip the tip of the thermometer to the surface of the water. Then wait a while until the thermometer shows a constant temperature, observed on the thermometer what is the temperature of the water. 


\subsubsection{Water transparency}

Measuring transparency to find out the brightness of the waters using a secchi disk that is lowered or dipped into the water until a secchi disk shows between visible and invisible to the eye and measured the depth of secchi disk using a ruler or meter.

\subsection{3. $\mathrm{pH}$}

The $\mathrm{pH}$ value is measured using a $\mathrm{pH}$ meter by inserting the tip of the $\mathrm{pH}$ meter into a water sample taken from the water until a constant reading and reading the number printed on the $\mathrm{pH}$ meter. Furthermore, $\mathrm{pH}$ measurements are carried out with $\mathrm{pH}$ paper to avoid errors in measuring the $\mathrm{pH}$ of water.

\subsubsection{Dissolved Oxygen}

Free measurement of dissolved oxygen in water is carried out in situ or carried out directly in the field. The work method of measuring dissolved oxygen is taking a sample of water using a bottle of $125 \mathrm{ml}$ (no air should enter), then adding $1 \mathrm{ml}$ of $\mathrm{MnSO}_{4}$ and $1 \mathrm{ml}$ of $\mathrm{NaOH}$ in KI, cover the bottle and shake it until the solution is homogeneous and sediment occurs. The next step is to add $1 \mathrm{ml}$ of concentrated $\mathrm{H}_{2} \mathrm{SO}_{4}$ and then close the bottle, shake it until the precipitate is gone and the solution is yellow, then insert $50 \mathrm{ml}$ of the sample into the 250 ml erlenmeyer. Titrate with $0.025 \mathrm{~N} \mathrm{Na}_{2} \mathrm{~S}_{2} \mathrm{O} 3$ until the solution is light yellow. Add 2 drops of starch, if a blue color appears then continue with titration of $0.025 \mathrm{~N} \mathrm{Na}_{2} \mathrm{SO}_{3}$ until the water becomes clear, then write the peniter volume obtained.

\subsection{5. $\mathrm{CO}_{2}$}

Measurements of free carbon dioxide levels in water are carried out in situ or carried out directly in the field. The working method of measuring carbon dioxide is to carefully add $50 \mathrm{ml}$ of water into the Erlenmeyer flask to avoid the effects of $\mathrm{CO}_{2}$ aeration or diffusion. Then drip 5 drops of PP (Phenolphthalein) indicator and turn the pumpkin calmly and regularly so that the PP indicator is spread evenly. If the color turns clear (colorless), then the solution includes free carbon dioxide. And tetration using $\mathrm{NaOH}$ solution to change the clear color to pink. Next write the peniter volume obtained.

\subsection{Data analysis}

Data analysis was performed by calculating abundance, diversity index, dominance index, and evenness index, and similarity index.

\subsection{Plankton abundance}

Determination of plankton abundance is based on the sweep method above the glass of Sedgwick Rafter. Plankton abundance is expressed quantitatively in the number of cells /liter. According to [4]. Plankton abundance is calculated based on the formula:

$$
\mathrm{N}=\mathrm{n} \times\left(\frac{V r}{V o}\right) \times\left(\frac{1}{V s}\right)
$$

With:

$\mathrm{N}=$ Amount (cell / liter)

$\mathrm{n}=$ Number of cells observed

$\mathrm{Vr}=$ Volume of filtered water $(\mathrm{ml})$

Vo $=$ Volume of water observed (at Sedgwick Rafter) $(\mathrm{ml})$

Vs $=$ Volume of filtered water (liters)

\subsection{Diversity Index}

The plankton diversity index describes the state of the plankton community whether it is stable (stable), more stable, very stable, or unstable in the habitat or station of the research. The species diversity index was analyzed using the ShannonWiener formula [7].

$$
\mathrm{H}^{\prime}=-\Sigma P i \ln P i
$$

With:

$H^{\prime}$ : Species Diversity Index

Pi: ni / N

this: Number of individuals in the i species

$\mathrm{N}$ : Total number of individuals

S: Number of Species

Table 1. Diversity index criteria

\begin{tabular}{lll}
\hline $\mathrm{N}$ & value of the & criteria \\
0 & diversity index & \\
\hline 1 & $\leq 1$ & Low organism community \\
2 & $1,0-3,0$ & $\begin{array}{l}\text { Community of medium } \\
\text { organisms }\end{array}$ \\
4 & $>3,0$ & High organism community \\
\hline
\end{tabular}

\subsection{Species Dominance Index}

The dominance of species is not the same spread of individuals and there is a tendency for a species to dominate. The calculation method used is the Simpson dominance index formula [4].

$$
\mathrm{C}=\Sigma(\mathrm{ni} / \mathrm{N})^{2}
$$

With:

C: Dominant index of species

This: The number of individuals per species

$\mathrm{N}$ : Total number of individuals for all species

Criteria: 
The value of $\mathrm{C}$ is between $0-1$, namely:

If $\mathrm{C}$ is close to $0(<0.5)$,

then there is no species that dominates.

If $C$ is close to $1(\geq 0.5)$,

then there is a species that dominates.

\subsection{Evenness Index}

Calculation of type evenness is done using a formula [7]. as follows:

$$
\mathrm{E}=\mathrm{H}^{\prime} / \mathrm{H}_{\max }
$$

\section{Description:}

E: Evenness index

$\mathrm{H}$ ': Diversity Index

Hmax: In s (s is the number of genera)

The index value ranges from $0-1$

If $\mathrm{E}$ approaches $0(<0.5)$ :

evenness among species is low, meaning that the individual wealth of each species is very different.

If $E$ approaches $1(\geq 0.5)$ :

evenness between species is relatively even or the number of individuals in each species is relatively similar.

\subsection{Similarity Index}

The similarity index of community structure between stations is calculated using the Sorenson formula [7]. namely:

Table 2. Value

\begin{tabular}{|c|c|}
\hline NO & $S=\frac{2 C}{A+B} X$ \\
\hline 1 & Plankton abundance (1ndividu/l) \\
\hline 2 & Abundance of Phytoplankton (individu/l) \\
\hline 3 & Zooplankton abundance (individu/l) \\
\hline 4 & Plankton Species Diversity \\
\hline 5 & Diversity of phytoplankton species \\
\hline 6 & Zooplankton Species Diversity \\
\hline 7 & Plankton Diversity Index $(\mathrm{H})$ \\
\hline 8 & Plankton Dominance Index \\
\hline 9 & Evenness Index \\
\hline
\end{tabular}

At station 1 there are 62 individuals/ 1 while zooplankton has only 21 individuals/l. the abundance of phytoplankton at station 2 is 45 individuals / 1 while zooplankton is only 4 individuals $/ 1$. the presence of phytoplankton is more observed due to the sampling time during the day where during the day phytoplants to the surface to look for sunlight while at noon zooplankton drops down.

The table above shows that the average value of phytoplankton abundance index is higher when
Information:

$A=$ Number of genera in sample $A$

$B=$ Number of genera in sample $B$

$\mathrm{C}=$ Number of genera in both samples

Criteria:

If $\leq 50 \%$, the community is relatively different

If $>50 \%$ then the community is relatively the same.

\section{Results and Discussion}

Based on the observations that have been made, it is obtained a table of results 4.1 where the table can show the plankton community structure found in the komering river in the city of Palembang, which represents four research stations which represent upstream, residential housing and downstream which empties into the Musi river. The table above shows that the average value of phytoplankton abundance index is higher when compared with zooplankton wherein all phytoplankton research stations are found more whereas zooplankton is found only slightly. this can be seen from the physical condition of the green river indicating that the abundance of phytoplankton is higher where the abundance of phytoplankto 
and 4 which show values of up to 91 individuals / river water. The highest plankton abundance is found at station 4, there are 95 plankton individuals where 91 phytoplankton are observed while zooplankton is only 4 individuals. This can be compared with station 1 which has an abundance of plankton totaling 83 individuals, there are 62 phytoplons and zooplankton there are 21 individuals who are mostly downstream compared to other stations. This location is at the mouth of the river, which is the entry point of the Musi river tide. This indicates that there are many zooplankton in the musi river.

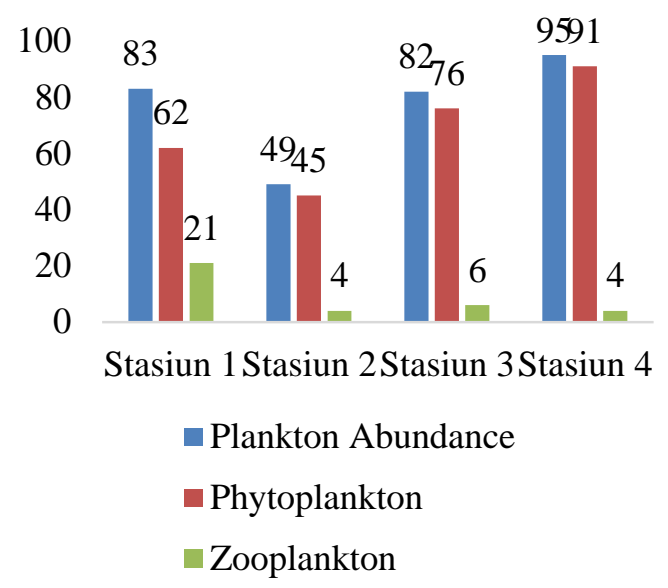

Figure 2. Plnkton Abundance

The abundance of plankton is certainly influenced by physical and chemical factors of water, this study shows the abundance of high phytoplankton associated with water quality that supports the life of phytoplankton. At stations 3 and 4 the abundance of phytoplankton is higher where the station has a high brightness value where phytoplankton can carry out photosynthesis perfectly because penetration of sunlight into the water is not blocked by turbidity.

\subsection{Diversity Index}

Based on figure 3, the highest plankton diversity index value is obtained at station 1 and the more upstream diversity index is getting smaller, this is due to the upstream or station 3 and 4 genome dominating, because the plankton diversity index is inversely proportional to the species dominance index. This can be caused by the condition of the acidic $\mathrm{pH}$ of the waters so that the development of plankton is disturbed.

The diversity index value shows the index value $<2.0$ plankton diversity at stations 1 and 2 shows an unstable index value in the ecosystem where if $\mathrm{H}^{\prime}>1-<2.0$ means the condition of the community of organisms in the ecosystem is unstable. Whereas at stations 3 and 4 show values $<1$, where if $\mathrm{H}^{\prime} \leq 1$ maka Community organisms are very unstable in the ecosystem. The diversity of the most plankton species in the research station is station 1 which shows 16 genera, at station 210 genera are found, station 3 is found 7 genera, while in station 4 there are 9 genera.

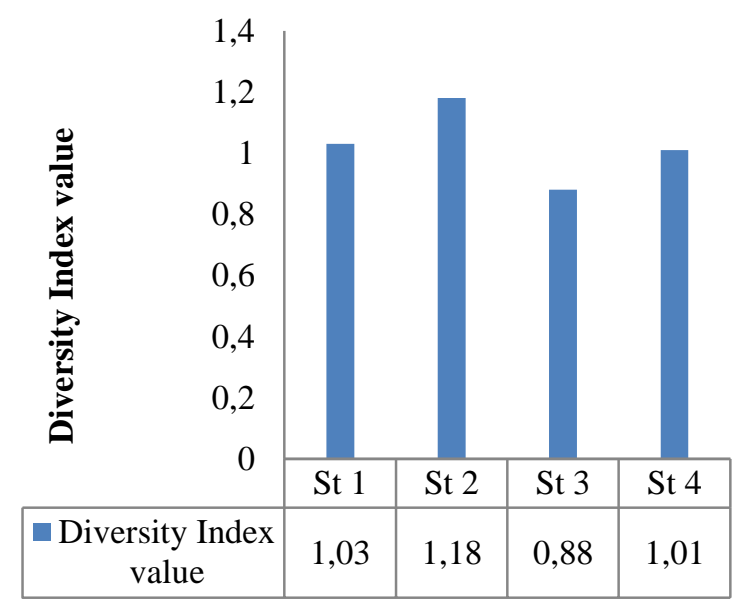

Figure 3. Diversity Index

\subsection{Dominance Index}

Based on the plankton dominance index diagram, it can be explained that at stations 3 and 4 there are dominating genera, with the existence of dominating genera, this also shows a very low diversity index value at stations 3 and 4 . The dominance index is inversely proportional to the diversity index because if there a genera that dominates then the development of other genera will be disrupted, so that only a few types of other organisms can live in that location due to the dominating genera.

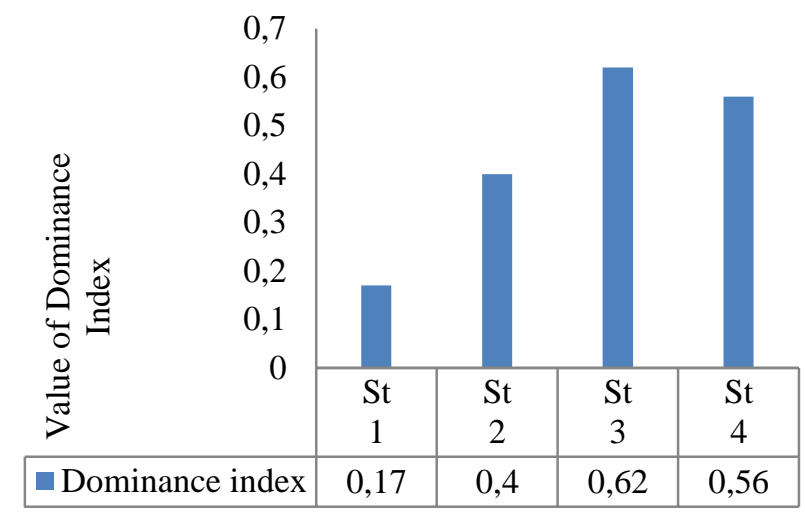

Figure 4. Dominance Index 
Plankton dominance index at station 1 shows an index value of 0.17 , station 2 is 0.4 , station 3 has an index value of 0.62 while at station 4 a dominance index value of 56 is obtained, at stations 3 and 4 there are genera dominate. The low diversity index at stations 3 and 4 is influenced by the presence of species that dominate due to ecological stress.

According to [8], if $\mathrm{C}<0.5$, it means that in the community structure of the biota we observe that no species dominates the other species to the extreme. This shows that the condition of the community structure is stable, environmental conditions are quite prime, and there is no ecological pressure (stress) on the biota in the habitat.

\subsection{Evenness Index}

Based on graph 4.4, the overall evenness index shows a number $<0.5$ which means that the evenness index between genera is uneven or the number of individuals in each genera is relatively different. The evenness index will be relatively the same if the evenness index is close to 1 or $\geq 0.5$. Whereas if the evenness index only shows a value below 0.5 , the individual wealth of each genera is very different. The lowest evenness index value is found at stations 3 and 4, this is due to the presence of certain genera dominating this station, which causes the distribution of genera in this station to be uneven. Whereas at station 1 and 2 evenness index $\geq 0.5$ where the value is close to 1 , which means that the genera at the station are spread evenly because there is no influence of snecies dominance on the station.

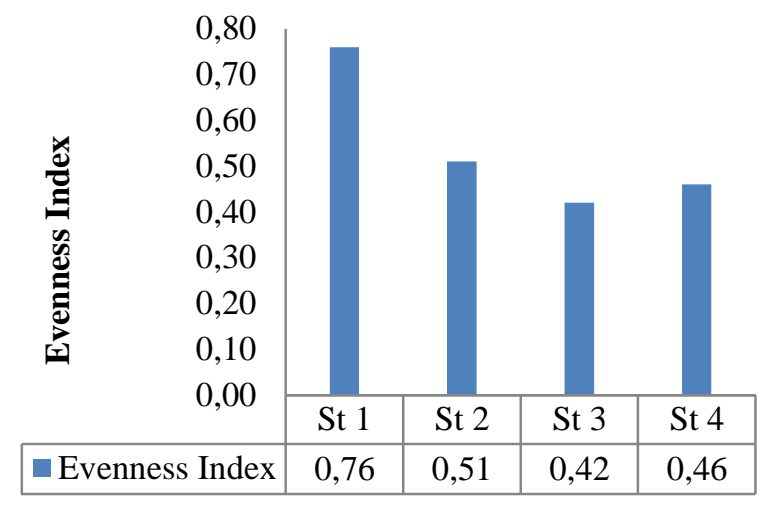

The index value obtained at each station is of course also related to the environmental conditions. At stations 3 and 4 are part of the representative of the upstream river where there are agriculture and residential areas, with these activities certainly have an impact on the condition of the aquatic biota community around them, agricultural activities certainly use herbicides, insecticide fertilizer etc., which if rain occurs, these elements will be carried by water to flow into the komering river body, and will suffer badly against aquatic organisms because these elements are toxic.

\subsection{Similarity Index}

Table 3. Similarity Index

\begin{tabular}{ccccc}
\hline station & I & II & III & IV \\
\hline I & & $69 \%$ & $52 \%$ & $40 \%$ \\
II & & $82 \%$ & $73 \%$ & $75 \%$ \\
III & & & \\
IV & & & & \\
\hline
\end{tabular}

Based on the calculations that have been done, the results of the similarity index between stations are obtained in table 4.2 in the comparison between all research stations averaging over $50 \%$, where if the Similarity Index between stations is above $50 \%$, the community between stations has similarities. [9], states that when the similarity index of two communities is compared to greater than $50 \%$, then the two communities compared can be considered as one community rather than being two different communities.
From the table above it can be explained that there are real differences in stations 1 and 4 where only $40 \%$ are obtained, which means that the similarity index between stations is relatively different. This shows the relationship with the physical-chemical properties of the waters between the four research stations is relatively the same, then the composition of plankton contained between stations is not much different. In addition, at stations 1 and 4 are the most distant research locations where the Komering river is a flowing river, the similarity index of the station is low. 


\subsection{Physical and Chemical Quality Analysis}

Table 4. Physical and Chemical Quality Analysis

\begin{tabular}{|c|c|c|c|c|c|}
\hline \multirow{2}{*}{ No } & Environmental Parameters & \multicolumn{4}{|c|}{ Observation Station } \\
\hline & & 1 & 2 & 3 & 4 \\
\hline 1. & $\begin{array}{l}\text { A. Pnysycal } \\
\text { Temperature }\left({ }^{\circ} \mathrm{C}\right)\end{array}$ & 28 & 29 & 29.5 & 30 \\
\hline 2. & Transparance $(\mathrm{Cm})$ & 20 & 28 & 38 & 39 \\
\hline & B. Chemistry & & & & \\
\hline 3. & $\mathrm{pH}$ (Unit) & 5.6 & 5.6 & 6.4 & 5.7 \\
\hline 4. & CO2 Dissolved (mg/L) & 11.30 & 10.20 & 8.50 & 7.60 \\
\hline 5. & DO Dissolved (mg/L) & 6.3 & 5.8 & 5.4 & 5.0 \\
\hline
\end{tabular}

\subsubsection{Temperature}

Water temperature at each station has a temperature that is not much different where on the downstream of the komering river (P1) has a temperature of $28^{\circ} \mathrm{C}$, station 2 has a temperature of $29^{\circ} \mathrm{C}$, station 3 has a temperature of $29.5^{\circ} \mathrm{C}$ while station 4 has a temperature of $30^{\circ} \mathrm{C}$. at this temperature normal for plankton growth.

\subsubsection{Transparancy}

The brightness at the research station is also very different where this can be caused by sampling

\begin{tabular}{lcccccc}
\hline \multirow{2}{*}{ Diversity Index } & \multicolumn{2}{c}{ Phsycs } & \multicolumn{3}{c}{ Chemistry } \\
\cline { 3 - 7 } & & Temperature & Transparancy & $\mathrm{pH}$ & $\mathrm{CO}_{2}$ & $\mathrm{DO}$ \\
\hline st 1 & 1.03 & 28 & 20 & 5.6 & 11.3 & 6.3 \\
st 2 & 1.18 & 29 & 28 & 5.6 & 10.2 & 5.8 \\
st 3 & 0.88 & 29.5 & 38 & 6.4 & 9.5 & 5.4 \\
st 4 & 1.01 & 30 & 39 & 5.7 & 7.6 & 5 \\
\hline
\end{tabular}

\subsection{3. $p H$}

The $\mathrm{pH}$ of a waters is very influential on the life of the organism in it. Because the $\mathrm{pH}$ of a waters determines what organisms live in it. At all water stations the $\mathrm{pH}$ is less than 7 , which means that these waters are quite acidic, but at station $3 \mathrm{pH}$ is 6.4 which means this is the highest $\mathrm{pH}$ among the 3 other stations which only have a $\mathrm{pH}<6$. Station 3 is located on plantations, rice fields, and there is natural vegetation on the banks of the river. This also greatly affects the growth of aquatic organisms.

\subsubsection{Dissolved Oxygen}

At station 1 there is a $6.3 \mathrm{DO}$ content where the DO content in station 1 is the highest when compared to other stations which only have a DO content of 5.8; 5.4 and 5.0. This can be proven that zooplankton is mostly found at station 1 because diffusion and photosynthesis.

\subsection{5. $\mathrm{CO}_{2}$}

environmental factors. At station 1, the brightness of $20 \mathrm{Cm}$ is obtained, which means that the brightness of water is low, where the color of station 1 water is brown due to water originating from the river Musi and entering the commering river because this location is located downstream of the river which is also the mouth of the komering river .Pada stasiun 2 memiliki kecerahan $28 \mathrm{~cm}$ which means that has brightness higher where at station 2 is located in a very dense residential area on the riverbank.

zooplankton requires sufficient oxygen for its survival, whereas at stations 2,3 and 4 zooplankton only have a small amount of DO content compared to station 1. [10], states that The source of input of dissolved oxygen in the waters can come from air

Carbon dioxide in the waters is a diffusion of $\mathrm{CO} 2$ from the air and the results of respiration of aquatic organisms, the amount of $\mathrm{CO} 2$ contained in a waters is also related to the number of organisms in the waters themselves. From the results obtained, it shows that the highest $\mathrm{CO} 2$ content is at station 1 , where at station 1 there are not many phytoplankton, because phytoplankton need $\mathrm{CO} 2$ in the process of photosynthesis and release oxygen, therefore the presence of DO at the station 1 also more. 
Analyzing correlation or regression with diversity of plankton

Tabel 5. Analyzing correlation or regression with diversity of plankton

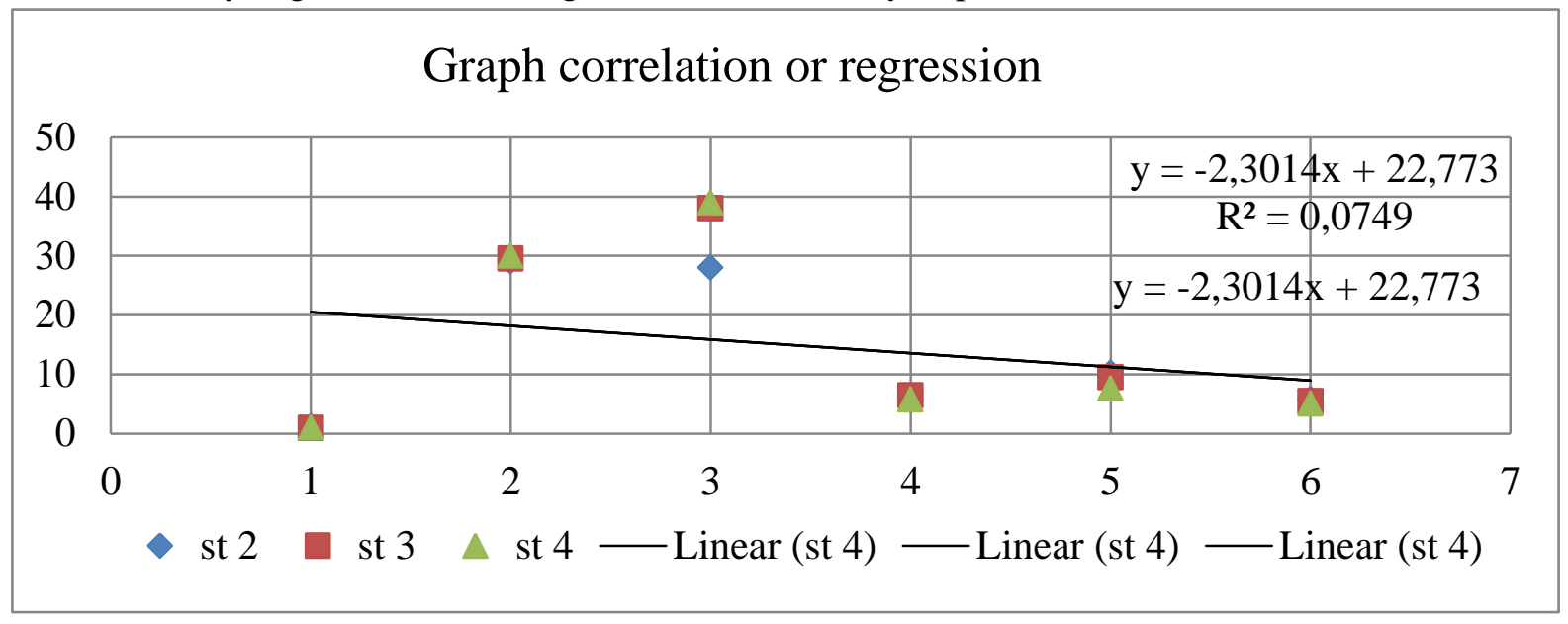

Figure 6. Graph correlation and regression

From the graph above it can be explained that the correlation of plankton diversity and physical water chemistry factors is strong at station 4 where station 4 has a relatively high value of chemical physics factors so it has a high correlation relationship with plankton diversity.

\section{Conclusion}

1. At agriculture area and upstream settelments area get the genera which dominates where the value of the standardized dominance index at agriculture area is 0.62 and upstream settlements area is 0.56 .

2. Plankton found at the research station were 10 classes consisting of 5 phytoplankton classes namely Bacillariophyceae, Chlorophyceae, Xanthophyceae, Cyanophyceae, Fragilariophyceae and 5 zooplankton classes namely Crustaceae, Flagellates, Rhizopods, Branchiopods and Nematodes.

3. The value of the diversity index shows the index value $<2.0$ plankton diversity at estuary area and settlements area shows an unstable index value in the ecosystem.

4. The highest $\mathrm{CO} 2$ content is in estuary areas, where there are not many phytoplankton in river estuaries.

\section{References}

[1] Patriono., E. Sagala, E.P, Wardhani, A,E. 2007. Inventarisasi Spesies Ikan Di Sungai Komering Kecamatan Madang Suku Ii Kabupaten Ogan Komering Ulu Timur, Sumatera Selatan. Journal Sainmatika. 1-7.

[2] Nontji.A.2008. Plankton Laut.LIPI Pres:Jakarta
[3] Wilhm, JL 1975. Biological Indicator of Pollution in River Ecological. Blackwell Scientific Publication. London.

[4] Edmondson, WT. 1959. Methods and Equiment in Freshwater biology 2nd ed. John Willey and Sons. Inc., NewYork, 1202.

[5] Mizuno, T. 1979. Illustration of the Freshwater Plankton of Japan. Revised edition. Osaka (J): Hoikusha Publishing Co., LTD.

[6] Sachlan, M. 1982. Planktonologi. Fakultas Peternakan Universitas Diponegoro, Semarang. Universitas Gajah Mada Press, Yogyakarta, 295.

[7] Odum, E.P. 1971. Foundamentals of Ecology. Third Edition. W.B. Sounders Company: Philadelphia.

[8] Basmi, J. 2000. Planktonologi : Plankton sebagai Bioindikator Kualitas Perairan. Fakultas Perikanan dan Ilmu Kelautan. Bogor: ii+59 hlm.

[9] Kendeigh, S.C. 1980. Ecology with Special Reference to Animals and Man. PrenticeHall of India, New Delhi.

[10] Arifin, R. 2009. Distribusi Spasial Dan Temporal Biomassa Fitoplankton (Klorofil-A) Dan Keterkaitannya Dengan Kesuburan Perairan Estuari Sungai Brantas, Jawa Timur. Skripsi. pada Departemen Manajemen Sumberdaya Perairan Fakultas Perikanan Dan Ilmu Kelautan Institut Pertanian Bogor : Bogor. 